\title{
Growth performance of Boer goat in relation to sex and type of birth at the Goat Research Station in Nepal
}

\author{
R Kadel ${ }^{*}$, S Malla, SH Ghimire, BB KC and PB Shrestha
}

Goat Research Station, Bandipur, Tanahun, Nepal

\begin{abstract}
This study was carried out at Goat Research Station, Bandipur, Tanahun, Nepal to evaluate the different factors affecting the growth performance of pure Boer goat since its arrival on 2015. A total of 225 kids of Boer goat born from 218 kidding does recorded between 2015 and 2019 were used for analysis of birth weight, weaning weight, eight month weight and yearling weight in response to sex and type of birth. The overall least square means for birth weight is $3.246 \pm 0.056 \mathrm{~kg}$, weaning weight is $17.86 \pm$ $0.105 \mathrm{~kg}$, eight month weight is $28.66 \pm 0.2 .6 \mathrm{~kg}$ and yearling weight is $45.10 \pm 0.218 \mathrm{~kg}$. The least square means across sex for birth weight, weaning weight, eight month weight and yearling weight were $3.368 \pm 0.090 \mathrm{~kg}, 18.42 \pm 0.226 \mathrm{~kg}, 31.69 \pm 0.415 \mathrm{~kg}$ and $49.29 \pm 0.707 \mathrm{~kg}$ for male and 3.136 $\pm 0.068 \mathrm{~kg}, 17.43 \pm 0.150 \mathrm{~kg}, 26.35 \pm 0.378 \mathrm{~kg}$ and $42.18 \pm 0.778 \mathrm{~kg}$ for female respectively. Sex and type of birth have significant effect on birth weight and weaning weight, while for eight month weight and yearling weight, sex have significant effect but no significant effect on type of birth. In conclusion, the overall growth performance of Boer goat in Goat Research Station was to the expectation and may increase on improvement of management and environmental effects.
\end{abstract}

Keywords: : growth performance, sex, type of birth, Boer goat

Bangladesh Animal Husbandry Association. All rights reserved.

Bang. J. Anim. Sci. 2020. 49 (2):166-169

\section{Introduction}

Nepal has above 11 million heads of goat (MoLD, 2017) with 4 distinctive breeds with possibility of existence of some other breeds/strains. Native goats have been characterized at phenotypic, chromosomal and molecular level. In the past, the goat development initiatives were taken by introduction of exotic goat breeds. Consequently exotic goat breeds such as Jamunapari, Barbari, Beetal, Sannen (dairy breed), Damascus, Mamber, Ajmeri etc. were introduced in Nepal through both authorized and unauthorized channel. These breeds were kept either in the government farm/Institute farm (IAAS) or distributed/spread to the farmers for upgrading existing goat population. The frozen semen of Kiko goat were also imported from New Zealand and first time AI was done in goat at Goat Farm, Bandipur and Pakhribas (Neopane and Sainju, 1995). Gradually the performance evaluations of these exotic goat breeds as well as their crosses with indigenous goats were started both on farm and on station condition. Unfortunately most of the goat breed introduced so far were not found to be better than our exiting goat breeds particularly Khari in terms of total output per doe per animal (Oli,1988; Upreti and Khanal, 1997; Pradhan and Gurung, 1985) in the hills of Nepal. Thus the more than decade long efforts to improve our indigenous goats went into vain. Thereafter, work started to explore the potential of indigenous goats. Pioneering works were carried out in Pakhribas Agricultural Centre and explored the possibility of improvement in Khari goats with selective breeding. The selection index based on weaning weight and twining ability was developed with the genetic parameter estimation from our own flock (Neopane, 1999). The response to selection was promising and selection response on weaning weight (4 month) and six months weight were found to be 2.77 and $9.6 \%$ respectively per generation (Pokharel and Neopane, 2006). They also reported that, with intensive selection pressure, the reproductive efficiency (twining rate) also improved significantly $(55 \%$ from $27 \%)$ in on farm condition. The authors have demonstrated that significant improvement in growth performance and twinning ability through selection within indigenous breed (Khari). Small ruminants particularly goats are regarded as handy source of cash to quench household needs, especially during a crisis, a popular approach amongst poor communities in the rural parts of the country. About $51 \%$ of the households in the country are 
keeping goats mainly for meat although other products/ byproducts such as manure, hair, hide and milk also has economic value. Recently Boer goat has been introduced and evaluation is being carried out in the country and already getting popularity among the farmers. Goat Research Station, Bandipur, Tanahun under Nepal Agriculture Research Council has also started research on the Boer goats with the implementation of Agriculture and Food Security Project on 2015. Boer goats are considered to be one of the most desirable mutton type breeds globally with the highest mature weight of 100 110 kg (Mustefa et. al., 2019). Boer goat can improve the productive performance of the native breeds in the many aspects, but before that its adaptability and performance in the new environment must be evaluated. Thus, this study was aimed to identify the factors affecting the on station growth performances of Boer goat and to evaluate the growth performance.

\section{Materials and Methods}

The study was conducted at Goat Research Station, situated at the Bandipur Rural Municipality of Tanahun district of Western hilly regions with the elevation of the station ranges 850 masl with the longitude of $84^{\circ} 38^{\prime} \mathrm{E}$ and latitude of $27^{\circ} 94^{\prime} \mathrm{N}$, and is $135 \mathrm{~km}$ west of capital city of Nepal, Kathmandu. Boer goats were managed at the farm condition providing ad libitum seasonal green forages and fodders (Napier grasses, Signal, Paspalum, Stylo, Ficussps, Morus alba, Bauhinia sps, and other locally avialble fodders) and commercially available concentrate pellets ( $1 \%$ of the body weight/head/day and fed all over the year). Clean water is provided on the water through. The healthcare of the goats was monitored by the veterinarians and technicians of the station with strategic deworming and on need treatment. All goats were vaccinated with the PPR and FMD.

A total of 225 kids of Boer goat born from 218 kidding does recorded between 2015 and 2019 were used for the analysis. The data recorded was birth weight (BW), weaning weight (WW), eight month weight (8MW) and yearling weight (YW). Data on body weight was recorded in the morning prior to feeding. The obtained data were analyzed using the General Linear Model procedure of Minitab 17 software. Means were compared using Tukey comparison. The model used for the analysis was

$Y_{i j k}=\mu+A_{i}+B_{j}+e_{i j k}$

where,

$Y_{i j k}$ is an observation, $\mu$ is the overall mean, $A_{i}$ is the fixed effect of the kid sex, $B_{j}$ is the fixed effect of the type of birth and $e_{i j k}$ is the random error

\section{Results}

The results of effect of sex on type of birth on birth, weaning, eight-month and yearling weight of the Boer goat is presented in the table 1 . The mean birth weight, weaning weight, eight-month weight and yearling weight of the Boer kids was found $3.24 \pm 0.05 \mathrm{~kg}, 17.86 \pm 0.10 \mathrm{~kg}, 28.66 \pm$ $0.20 \mathrm{~kg}$ and $45.10 \pm 0.22 \mathrm{~kg}$ respectively. The result also indicates that the male kids had the higher weight at birth $(p=0.04)$ and at weaning $(p=0.002)$ than female kids. The buckling had significantly higher body weight $(p<0.0001)$ at eight-month weight and yearling weight when compared to the doeling. The effect of type of birth (single, twin and triplet) has significant effect on birth weight $(p=0.002)$ and weaning weight $(p<0.0001)$ but non-significant on eightmonth and yearling weight.

Table 1: Least square means (LSM) and standard error (SE) of body weight from birth to yearling of Boer goat at GRS, Bandipur

\begin{tabular}{|c|c|c|c|c|c|c|c|c|}
\hline \multirow{2}{*}{$\begin{array}{l}\text { Sources of } \\
\text { Variation }\end{array}$} & \multicolumn{2}{|c|}{$\begin{array}{l}\text { Birth Weight } \\
(\mathbf{k g})\end{array}$} & \multicolumn{2}{|c|}{$\begin{array}{c}\text { Weaning weight } \\
(\mathbf{k g})\end{array}$} & \multicolumn{2}{|c|}{$\begin{array}{l}\text { Eight month weight } \\
\text { (kg) }\end{array}$} & \multicolumn{2}{|c|}{ Yearling weight $(\mathbf{k g})$} \\
\hline & $\mathbf{N}$ & LSM \pm SE & $\mathbf{N}$ & LSM \pm SE & $\mathbf{N}$ & LSM \pm SE & $\mathbf{N}$ & LSM $\pm S E$ \\
\hline Overall Mean & 225 & $3.24 \pm 0.05$ & 171 & $17.86 \pm 0.10$ & 90 & $28.66 \pm 0.20$ & 56 & $45.10 \pm 0.22$ \\
\hline Kid Sex & & $p=0.04$ & & $p=0.002$ & & $p<0.0001$ & & $p=0.0001$ \\
\hline Male & 107 & $3.36 \pm 0.13^{\mathrm{a}}$ & 75 & $18.42 \pm 0.23^{a}$ & 39 & $31.69 \pm 0.41^{\mathrm{a}}$ & 23 & $49.29 \pm 0.71^{\mathrm{a}}$ \\
\hline Female & 118 & $3.13 \pm 0.06^{b}$ & 96 & $17.43 \pm 0.15^{\mathrm{b}}$ & 51 & $26.35 \pm 0.38^{\mathrm{b}}$ & 33 & $42.18 \pm 0.78^{b}$ \\
\hline Type of Birth & & $p=0.002$ & & $p<0.0001$ & & & & \\
\hline Single (44) & 22 & $3.63 \pm 0.13^{\mathrm{a}}$ & 32 & $20.84 \pm 0.29^{a}$ & 12 & $28.93 \pm 0.35$ & 7 & $45.30 \pm 0.50$ \\
\hline Twin (71) & 142 & $3.18 \pm 0.81^{\mathrm{b}}$ & 109 & $17.22 \pm 0.62^{b}$ & 60 & $28.75 \pm 0.35$ & 41 & $45.12 \pm 0.35$ \\
\hline Triplet (13) & 39 & $3.04 \pm 0.13^{b}$ & 30 & $17.01 \pm 0.78^{b}$ & 18 & $28.18 \pm 0.31$ & 8 & $44.81 \pm 0.42$ \\
\hline
\end{tabular}




\section{Growth rate of Boer goat in Nepal}

\section{Discussion}

The birth weight of the Boer goats in this study was comparable to the reports of Mustefaet. al. (2019), Abd-Allah et. al. (2015) and Đuričićet. al. (2012) which was $3.05 \pm 0.06 \mathrm{~kg}, 3.08 \mathrm{~kg}$ and $3.48 \pm 0.04 \mathrm{~kg}$ respectively. The birth weight in this study was higher than findings reported by Faruque (2010), Upreti and Khanal (1997), Neopane (1997), Rasali and Khanal (2002), Kalachhapati (2006), Sapkota (2007) andPandey (2007) among Black Bengal and Khari goats respectively. The birth weight of male and female kids was found slightly lower than findings of Đuričićet. al. (2012) which was $3.66 \pm 0.40 \mathrm{~kg}$ and $3.41 \pm 0.09 \mathrm{~kg}$ for male and female respectively but significantly higher than that of Khari and Khari crosses in findings of Rasali and Khanal (2002).The birth weight of the single kids is higher than twins and triplets supported by the findings of Faraque et. al. (2010) and Hasanet. al. (2014).The weaning weight of the Boer kid was found higher than findings of Abd-Allah et. al. (2015) on Boer goat $(12.84 \mathrm{~kg})$, which is also significantly higher than the weaning weight of local Khari goats in findings of Neopane (1997), Rasali and Khanal (2002), Kalachhapati (2006), Sapkota (2007) and Pandey (2007).

The eight months weight of the Boer kids was found comparatively higher than the nine months weight of Khari goats on findings of Neopane (1997), Rasali and Khanal (2002), Kolachhapati (2006) and Sapkota (2007) which was $10.43 \pm 0.17 \mathrm{~kg}, 14.19 \pm 0.87 \mathrm{~kg}, 18.18 \pm 0.12 \mathrm{~kg}$ and $15.83 \pm 0.25 \mathrm{~kg}$ respectively. Similarly for the yearling weight, the finding was higher amongst the findings of Abd-Allah (2015) and Mustefaet. al. (2019) in comparison of Boer goat, which is also higher than the yearling weight of the indigenous Khari goat compared to findings of Rasali and Khanal (2002).

\section{Conclusion}

Boer goat are recognized for the fast growing rate breeds and the overall performance of Boer goat in Goat Research Station, Bandipur has findings of better weight gain throughout the year. Compared to the factors of sex and type of birth, male kid body weight was found higher than female kids but single born kids have higher body weight till the weaning age, but after weaning, there is no difference on weight till the yearling on type of birth. Based on the study, Boer goat has overall good growth performance in farm condition of Nepal.

\section{Acknowledgment}

The Authors want to thank all the staffs of Goat Research Station, Bandipur, Tanahun, Animal Breeding Division and Agriculture and Food Security Project.

\section{Conflict of interest}

There is no conflict of interest among the authors.

\section{References}

Abd-Allah S, R Salama, MI Mohamed, M Mabrouk, AI Kadry and SM Ahmed (2015). A comparative study on reproductive and productive performance of Boer and Baladi goats raised under similar environmental conditions in Egypt. International Journal of Chem Tech Research 8(9): 225-236.

Bhattarai N (2012). Genetic potentialities of Khari goat in Nepal: A Review. Proceedings of sixth national convention of NASA, 25-26 September, 2012. Nepal Animal Science Association, (NASA) Kathmandu, Nepal.p158163.

Đuričić D, J Grizelj, T Dobranić, I Harapin, S Vince, P Kočila, I Folnožić, M Lipar, G Gračner and M Samardžija (2012). Reproductive performance of Boer goats in a moderate climate zone. Veterinarski Arhiv 82(4): 351-358.

Faruque S, SA Chowdhury, NU Siddiquee and MA Afroz (2010). Performance and genetic parameters of economically important traits of Black Bengal goat. Journal of Bangladesh Agriculture University 8(1): 72-78.

Hasan F, B Jakariab and A Gunawan (2014). Genetic and phenotypic parameters of body weight in Ettawa Grade Goats. Media Peternakan 37(1): 8-16.

Kolachhapati MR (2006). Phenological study of hill goats under different management systems and nutritional regimes. Ph.D. Thesis. Institute of Agriculture and Animal. Sciences, Rampur, Chitwan, Nepal. P 148.

MoLD (2017). Livestock Statistics of Nepal. Planning, Monitoring and Evaluation Division, Singhadurbar, Kathmandu, Nepal

Mustefa A, S Gizaw, S Banerjee, A Abebe, M Taye, A A Areaya and S Besufekad (2019). Growth performance of Boer goats and their F1 and F2 crosses and backcrosses with Central Highland goats in Ethiopia. Livestock Research for Rural Development 31:1-17.

Neopane SP (1997). Genetics of productive traits in a Nepalese Hill goat flock. Ph.D. Thesis. University of London, UK. p278.

Neopane SP (1999). Improvement of hill goats through selection. Proceedings of 3rd National Workshop on Science and Technology, March 8-11, 1999, Royal Nepal Academy of Science and Technology, Kathmandu, Nepal, pp 11051110. 
Neopane SP and AP Sainju (1995). Performance of Kiko crossbred goats in the mid hills of Nepal, Proceedings of the $2^{\text {nd }}$ National Animal Science Convention (NASA), August 7-10, 1995, Lalitpur, Nepal, pp 100-104.

Oli KP (1988). Goat breed comparison study in Hattikharka Panchayat. Nepalese Journal of Animal Science 4(4):1-11.

Pandey SR (2007). Performance of Khari goat and its crosses in the hills of Tanahu district, Nepal. M.Sc. Thesis. . Institute of Agriculture and Animal. Sciences, Rampur, Chitwan, Nepal. p84.

Pokharel PK and SP Neopane (2006). Study on productivity improvement of hill goat through selective breeding programme, Nepal Journal of Science and Technology 7: 1-5.

Pradhan SL and NK Gurung (1985). Comparative performance of Khari goats and its crossbred with Jamunapari goat at central goat farm, Bandipur, Nepalese Journal of Animal Science 1(1): 35-45.

Rasali DP and RC Khanal (2002). Comparative performance of indigenous crossbreds of goats at Lumle Farm, Nepal. Nepal Journal of Science and Technology 4:129-134.

Sapkota S (2007).Comparative performance of goat representing eastern western and central regions of Nepal. M.Sc. Thesis. . Institute of Agriculture and Animal. Sciences, Rampur, Chitwan, Nepal. P138.

Upreti CR and RR Khanal (1997). Comparative performance of seven goat breeds at ARS Bandipur Proceedings of $2^{\text {nd }}$ Workshop on Livestock and fisheries Research, Sept 24-25, 1997, Khumaltar, Lalitpur, Nepal. pp 24-28. 